\title{
Prevalence and pattern of morbidities among children at a private school in rural area of Koppal, Karnataka
}

\author{
M Nimbannavar S. ${ }^{1}$, Mane V. ${ }^{2 *}$, Yuvaraj B Y. ${ }^{3}$ \\ DOI: https://doi.org/10.17511/ijphr.2017.i2.04 \\ 1 Smita M Nimbannavar, Assistant Professor, Department of Community Medicine, Koppal Institute of Medical Sciences, Koppal, Karnataka, \\ India. \\ 2* Vijaykumar Mane, Assistant Professor, Department of Community Medicine, Koppal Institute of Medical Sciences, Koppal, Karnataka, \\ India. \\ 3 Yuvaraj B Y, Professor \& Head, Department of Community Medicine, Koppal Institute of Medical Sciences, Koppal, Karnataka, India.
}

Introduction: Children are the most valued resources and their health is the biggest investment for any country in the world. Morbidity rates among school children in our country are among the highest in the world and are the common causes of low school enrolment, high absenteeism, early dropout and poor classroom performance. Frequent and regular health check-ups are considered as an ideal platform for earlier detection and prompt treatment of the health problems among them. Objective: To study the prevalence and pattern of morbidities among Primary school children in the study setting. Methods: A cross sectional study was conducted among school children at a Private Primary school situated in the Katharki village, a rural area of Koppal. A pretested and semi structured questionnaire was used for data collection and analyzed using Epiinfo software version 3.5.4. Results: The prevalence of morbidity was found to be among $79(44.63 \%)$ of children and the most common morbidities were Dental Fluorosis and Dental caries followed by Upper respiratory tract infections. Morbidity was marginally higher among male children and was found to be directly proportional to the age group of the children in our study. Conclusion: There is a need to focus on the regular health check-up of school children to improve their health status so that they can attain their full potential and become productive citizens of the country.

Keywords: Morbidity pattern, Prevalence, School child

Corresponding Author

Vijaykumar Mane, Assistant Professor, Department of Community Medicine, Koppal Institute of Medical Sciences, Koppal, Karnataka, India.

Email: vijaymane01@gmail.com

\section{How to Cite this Article}

Nimbannavar SM, Mane V, Yuvaraj B Y. Prevalence and pattern of morbidities among children at a private school in rural area of Koppal, Karnataka. Public Health Rev Int J Public Health Res. 2017;4(2):53-58.

Available From

https://publichealth.medresearch.in/index.php/ijphr/ article/view/62
To Browse

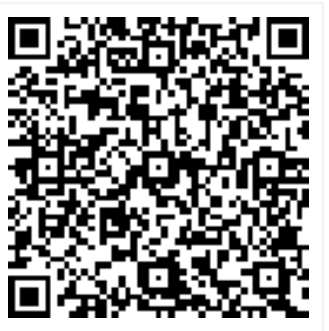

Manuscript Received 2017-04-05

Conflict of Interest No
Review Round 1 2017-04-15

Funding

Nil

$\begin{gathered}\text { Review Round } 2 \\ \text { 2017-04-24 }\end{gathered}$
Ethical Approval
Yes

Review Round 2

Yes
Review Round 3

Accepted 2017-04-30

Plagiarism $\mathbf{X}$-checker $9 \%$

(C) 2017 by Smita M Nimbannavar, Vijaykumar Mane, Yuvaraj B Y and Published by Siddharth Health Research and Social Welfare Society. This is an Open Access article licensed under a Creative Commons Attribution 4.0 International License https://creativecommons.org/licenses/by/4.0/ unported [CC BY 4.0]. 


\section{Introduction}

Children are the most valued resources and their health is the biggest investment for any country in the world. No nation however advanced can afford to neglect this supreme asset. Habits either good or bad formed at this stage of life will be carried to the adult age, old age and even to the next generation.

A child spends more time at school than anywhere else, except home. School is considered as a sacred place where children acquire knowledge, skills, intelligence and a place where overall development of the child takes place. These children in turn can influence health behavior of other children, their families and community.

School children alone account for $20 \%$ of the total population in our country and constitute a highly vulnerable group [1]. The current health status of school children in our country is very unsatisfactory. Even though mortality rates are low in this age group, morbidity rates are among the highest in the world and there are wide variations in their pattern from one place to another.

Surveys conducted in different parts of the country suggest that the most common morbidities among school going children are malnutrition, dental caries, infectious diseases, intestinal parasites, diseases of skin, eye and ear [1] [2] [3] [4]. Majority of these ailments can be detected and corrected early, so that they can catch-up with their education and become normal future promising adults of the country [5]. Research also indicates that malnutrition and poor health are among the most common causes of low school enrolment, high absenteeism, early dropout and poor classroom performance [6] [7].

The School health services in India dates back to 1909, when for the first time medical examination of school children was carried out in Baroda city and unfortunately even after 100 years, they are not so well organised because of many reasons like peculiar rural conditions, economic problems, nonavailability of medical personnel \& other unfavourable conditions [3] [4] [8].

They are considered as an ideal platform for earlier detection and prompt treatment of the health problems among school children. Early identification of childhood illnesses through frequent and regular health check-ups can also help prevent further complications [6].
With this background, the present study was undertaken to develop an epidemiological data about morbidity pattern among school going children in the study area for effective planning of interventions.

Objective of the study: 1) To study the prevalence and pattern of morbidities among Primary school children in the study setting.

\section{Materials and Methods}

\section{Design of study: Cross sectional study}

Study setting: The present study was conducted at a Private Primary school in the Katharki village, which is situated around $30 \mathrm{~km}$ from Koppal city during the month of November 2016 as a part of "General Health checkup and Screening camp" for school children organized by the Department of Community Medicine, KIMS, Koppal.

Study population: All the school children of a Private High Primary school, Katharki village, Koppal.

Data collection: All the school children of either sex studying from 1st to 7th standard were included in the study. A pretested and semi structured questionnaire was used to collect information regarding demographic characteristics and any current health problems in the child after taking their assent and informed consent from their teachers. A thorough Health check-up of children was also done to look for presence of various morbidities like skin diseases, eye problems, respiratory tract infections etc.

Those who were found to be suffering from minor illnesses were given medication while those having illnesses which couldn't be managed in the camp, were referred to nearest Health center. Health education regarding personal hygiene was also imparted to the children in the camp.

Exclusion criteria: Students absent on the day of data collection were excluded from the study.

Statistical analysis: Data was analyzed using Epiinfo software version 3.5.4.

\section{Results}

The total number of students present on the day of camp was 177 and all were included in the study. Majority of them i.e. 109 (61.58\%) were males and male to female ratio in our study was 1:0.6. 
The age of school children ranged from 6 to 12 years with a mean of $8.40 \pm 1.64$. The overall prevalence of morbidity in our study was found out to be among $79(44.63 \%)$ of children. Out of them, five children were found to be suffering from more than one morbidity.

Figure No. 1: shows the distribution of school children according to their morbidities. The most common morbidities were Dental Fluorosis seen among 30 (16.94\%) and Dental caries among 28 (15.81) of children followed by Upper respiratory tract infections among 11 (6.21\%).

Figure No. 1: Distribution of study subjects according to their morbidity

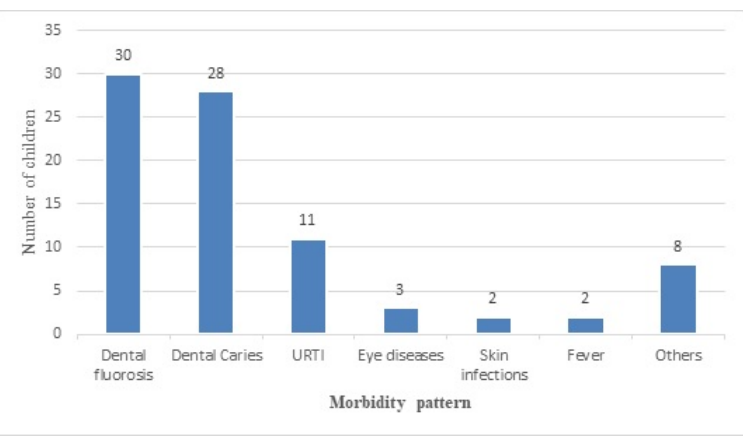

Table No. 1: shows sex-wise distribution of school children according to their morbidities. The overall prevalence of morbidity was marginally higher among male children compared to their female counterparts. Also, the prevalence of any morbidity was higher among male children in our study except for dental caries and skin infections as seen in the table.

Table No. 1: Gender wise distribution of study subjects according to their morbidity

\begin{tabular}{|l|l|l|l|l|}
\hline \multirow{2}{*}{ SI. No. } & \multirow{2}{*}{ Morbidity } & \multicolumn{3}{|c|}{ Number of children N (\%) } \\
\cline { 3 - 5 } & & Male & Female & Total \\
\hline 1 & Dental fluorosis & $20(18.34)$ & $10(14.70)$ & $30(16.94)$ \\
\hline 2 & Dental Caries & $12(11)$ & $16(23.52)$ & $28(15.81)$ \\
\hline 3 & Upper respiratory tract infections & $8(7.33)$ & $3(4.41)$ & $11(6.21)$ \\
\hline 4 & Eye diseases & $3(2.75)$ & $0(0)$ & $3(1.69)$ \\
\hline 5 & Skin diseases & $1(0.91)$ & $1(1.47)$ & $2(1.12)$ \\
\hline 6 & Fever & $2(1.83)$ & $0(0)$ & $2(1.12)$ \\
\hline 7 & Others & $8(7.33)$ & $0(0)$ & $8(4.51)$ \\
\hline 8 & No morbidity & $59(54.12)$ & $39(57.35)$ & $98(55.36)$ \\
\hline & Total* & 109 & 68 & 177 \\
\hline
\end{tabular}

* Number of children may exceed total number as five children were suffering from more than one morbidity
Table No. 2: Age wise distribution of study subjects according to their morbidity

\begin{tabular}{|l|l|l|l|l|l|}
\hline \multirow{2}{*}{$\begin{array}{l}\text { SI. } \\
\text { No. }\end{array}$} & \multirow{2}{*}{ Morbidity } & \multicolumn{4}{|c|}{ Number of children N (\%) in different } \\
\cline { 3 - 6 } & & $\begin{array}{l}6-7 \\
\text { years }\end{array}$ & $\begin{array}{l}8-9 \\
\text { years }\end{array}$ & $\begin{array}{l}10-12 \\
\text { years }\end{array}$ & Total \\
\hline 1 & Dental fluorosis & $9(12)$ & $7(14.28)$ & $13(24.52)$ & $30(16.94$ \\
\hline 2 & Dental Caries & $18(24)$ & $7(14.28)$ & $1(1.88)$ & 28 \\
& & & & $15.81)$ \\
\hline 3 & Upper respiratory tract & $2(2.66)$ & $5(10.20)$ & $4(7.54)$ & $11(6.21)$ \\
\hline 4 & Eye diseases & $1(1.33)$ & $0(0)$ & $2(3.77)$ & $3(1.69)$ \\
\hline 5 & Skin diseases & $0(0)$ & $1(2.04)$ & $1(1.88)$ & $2(1.12)$ \\
\hline 6 & Fever & $2(2.66)$ & $0(0)$ & $0(0)$ & $2(1.12)$ \\
\hline 7 & Others & $2(2.66)$ & $2(4.08)$ & $4(7.54)$ & $8(4.51)$ \\
\hline 8 & No morbidity & $45(60)$ & $28(57.14)$ & $28(52.83)$ & 98 \\
& & & & & $(55.36)$ \\
\hline & Total* & 75 & 49 & 53 & 177 \\
\hline
\end{tabular}

* Number of children may exceed total number as five children were suffering from more than one morbidity

Table No.2: shows age-wise distribution of school children according to their morbidities. The overall prevalence of morbidity was directly proportional to the age group of children with highest prevalence in $10-12$ year age group and lowest in $6-7$ year age group.

With respect to individual morbidities, it was observed that the prevalence of dental fluorosis was directly proportional to the age group of children in our study whereas the prevalence of dental caries was inversely proportional as evident from the table.

\section{Discussion}

School health surveys offer an excellent opportunity to screen a large number of pediatric children with minimum resources, providing an opportunity to implement primary as well as secondary prevention at the same time. Many studies have been done in different parts of the country to ascertain the health status of school children and to find out the pattern of various morbidities among them.

The present study findings revealed that the overall prevalence of morbidity among school children was high $(44.63 \%)$ consistent with the findings of Nigudgi et.al [1] done in urban area of Gulbarga, Karnataka and Vidya Rani et.al [7] in rural area of Uttar Pradesh. 
However, many other studies done in different parts of the country have found out even higher prevalence of morbidities among school children [24,8-13]. This difference in the prevalence of morbidities could be due to differences in the profile of study participants, geography of the study settings, study tools used, seasonal variation in time frame of study etc.

The most common morbidities among study subjects in our study were Dental problems like Fluorosis and Caries followed by Upper respiratory tract infections. Similar to the findings of our study, dental problems especially dental caries were the most common morbidities as reported by many other studies [1] [2] [6] [7] [8] [11] [13].

The overall prevalence of morbidities was higher among male children in our study similar to the findings of other studies done in different parts of the country [2] [4] [11]. On the contrary, few other studies have found out higher prevalence of morbidities among female children as opposed to males [1] [3] [6] [10] whereas a couple of studies have found out equal prevalence among both [7] [8]. The prevalence of morbidity was directly proportional to the age group of children in our study.

Similar relation was found in many other studies [2] [3] [4] [7] [10], however the prevalence of morbidities in all these studies falls suddenly around the age group 10 to 12 years unlike the present study. The present study has a limitation of being conducted in a single private school located in rural community that too during winter season which might have given rise to a peculiar pattern of morbidity incidental to the geographic location and season respectively.

\section{Conclusion}

The health status of the school children in the present study was unsatisfactory and it was unfortunate that most of the morbidities observed among them were preventable. Further, the health of the child can be restored and improved, provided that the disease is detected early and remedied by a well-organized school health programme.

Thus there is a definite need to focus on the periodical and regular health check-up of school children along with health education to improve their health status so that they can attain their full potential and become productive citizens of the country.

\section{Reference}

01. Nigudgi SR, Reddy S, Kapate R. Morbidity pattern among School children of Gulbarga city. Medica Innovatica. 2012;1(2)20-23.

[Crossref]

02. N Saluja, S Garg, H Chopra. Prevalence of Morbidity and Morbidity pattern in School Children (5-11 Yrs) in urban area of Meerut. The Internet Journal of Epidemiology. 2010;9(2)1-5. [Crossref]

03. Kaushik A, Bansal A, Jain PK, Kumar S, Yadav R $\mathrm{K}$, Singh SP. Morbidity pattern and their socio-d emographic co-relates among rural primary scho ol children in eastern Uttar Pradesh- A cross sec tional study. Ind J Comm Heal. 2014;26 (1)30-6 [Crossref]

04. Shinde M, Trivedi A, Joshi A. Morbidity pattern among school children of rural area of Obaidullaganj block of Raisen District of Madhya Pradesh. Int J Adv Med. 2015;2(2)144-146.

DOI: 10.5455/2349-3933.ijam20150513 [Crossref]

05. Suryakanth AH. Community medicine with recen $\mathrm{t}$ advances. 4th ed, Jaypee Bro Medi. 2017;634. [Crossref]

06. Joice S, Velavan A, Natesan M, Singh Z, Purty A J, Hector H. Assessment of Nutritional Status an d Morbidity Pattern among School Children of Ru ral Puducherry. Acad med J Ind. 2013;1(1)32-5. [Crossref]

07. Rani V, Srivastava DK, Jain PK, Kumar S, Singh NP, Dixit AM. Morbidity Pattern among Primary School children in a Rural Area of Uttar Pradesh. Natl J Community Med. 2014;5(4)392-6. [Crossref]

08. Mhaske MS, Khismatrao DS, Kevin F, Pandve HT, Kundap RP. Morbidity pattern and personal hygiene in children among Private Primary school in Urban area- Are the trends changing?. J Family Med Prim Care. 2013;2(3)266-269. doi: 10.4103/2249-4863.120753 [Crossref]

09. Nigudgi SR, Patil VM, Tengilkar SG, Shrinivasreddy B, Vijayanath V. A study to assess the morbidity pattern among School going children of Gulbarga city. Indian Journal of Public Health Research and Development. 2013;4(4)108-111.

DOI: $\quad 10.5958 /$ j.0976-5506.4.4.152 [Crossref] 
10. Kausar H, Sambutwad RC, Shafee M. Prevalence of morbidity and morbidity pattern among primary school children in rural area of Jalna, Maharashtra, India. Int J Community Med Public Health. 2016;3(6)1623-7.

DOI: [Article] [Crossref]

11. Sehgul RK, Garg R, Anand S, Dhot PS, Singhal P. A study of the morbidity profile, personal hygiene and nutritional status of school children in rural areas of district Ghaziabad in Uttar Pradesh. J of Evolution of Med and Dent Sci. 2015;4(72)12574-80.

DOI: $\quad 10.14260 /$ jemds/2015/1810 [Crossref]
12. Eram U, Tamanna Z, Khalique N, Deoshree. A study of Morbidity pattern and Personal Hygiene among school children of Rural areas of Aligarh. Indian J Appl Res. 2016;6(12)74-76.

[Crossref]

13. Kulkarni MM, Varun N, Rathi P, Eshwari K, Ashok K, Kamath VG. Health status of school children in rural area of coastal Karnataka. Med J DY Patil Univ. 2016;9(1)31-5.

DOI: 10.4103/0975-2870.172424 [Crossref] 